\title{
Spatial and temporal variability of soil loss in gully erosion in upper Blue Nile basin, Ethiopia
}

\author{
Alemsha Bogale $^{1,2} \cdot$ Dessalew Aynalem ${ }^{2} \cdot$ Anwar Adem $^{2,3}$ (D) $\cdot$ Wolde Mekuria ${ }^{4} \cdot$ Seifu Tilahun $^{2}$
}

Received: 24 August 2019 / Accepted: 30 March 2020 / Published online: 13 April 2020

(c) The Author(s) 2020

\begin{abstract}
Gully erosion has many negative impacts on both cultivated and grazing lands in Ethiopian highlands. The present study was conducted in Chentale watershed, Ethiopia, to quantify the contribution of gully erosion, and to assess its temporal changes. Within the Chentale watershed, we selected a sub-watershed (104.6 ha) and nested gully catchment, and gauged for stream flow and sediment concentration data in 2015 and 2016. We measured gully dimensions before and after the onset of the rainy season in 2016 to determine soil loss due to gully erosion. The temporal changes of gully expansion were determined by digitizing gully plain area from Google earth images taken in 2005 and 2013. The results support that gullies were expanding at higher rate in recent years. Area covered by gullies in the watershed increased from 1.84 to 3.43 ha between 2005 and 2013, indicating that the proportion of the watershed covered by gullies was nearly doubled in the investigated period. The estimated soil loss from the main watershed and gullies catchment was 6 and $2 \mathrm{t} \mathrm{ha}^{-1}$ year $^{-1}$ in 2015 , and was 7 and $9 \mathrm{t} \mathrm{ha}^{-1}$ year $^{-1}$ in 2016, respectively. The results support that gullies were the main contributors of soil erosion in the watershed, and that integrated soil and water conservation measures are required to reduce soil erosion.
\end{abstract}

Keywords Chentale $\cdot$ Google earth $\cdot$ Gully erosion $\cdot$ Soil loss

Alemsha Bogale

galemsha35@gmail.com

Dessalew Aynalem

workudessu@gmail.com

Anwar Adem

anwarasefa@gmail.com

Wolde Mekuria

w.bori@cgiar.org

Seifu Tilahun

satadm86@gmail.com

1 Department of Water Technology, Bahir Dar Polytechnic College, Bahir Dar, Ethiopia

2 Faculty of Civil and Water Resources Engineering, Bahir Dar University, Bahir Dar, Ethiopia

3 Department of Natural Resource, Bahir Dar University, Bahir Dar, Ethiopia

4 International Water Management Institute (IWMI), Addis Ababa, Ethiopia

\section{Introduction}

Soil erosion consists of a series of natural processes that move earth and rock material (Tebebu et al. 2010), and the natural processes can be accelerated by human interventions. Soil erosion is a global problem and has both onsite and offsite effects. Of the onsite effects, soil erosion could deteriorate soil fertility and reduce agricultural productivity (Desta and Adugna 2012). Soil erosion could cause siltation and sedimentation of water infrastructures such as irrigation and hydropower dams (Nyssen et al. 2002), and affect water quality negatively (Carey 2006; Moges et al. 2016).

Soil erosion has different forms including sheet, rill and gully erosion. Among the different forms of soil erosion, gully erosion resulted in permanent damages such as depreciation in land value, lowering of water table, dissection of agricultural and grazing lands (Lakew and Basin 2012), and requires more effort to control. Similar to other parts of the world, gully erosion in the highlands of Ethiopia is mainly attributed to excessive removal of vegetation and has led to reduce soil moisture in the agricultural lands and contributed to the reduction in crop yield (Descheemaeker et al. 2006a, b; Nyssen et al. 2002, 2004). 
Studies like Desta and Hurni (2011), Hurni (1988) and Moges and Holden (2008) indicated that the government of Ethiopia in collaboration with local communities and international donors exerted different kinds of efforts to rehabilitate degraded lands since the 1985 . Today, the Productive Safety Net and sustainable land management programs continue to implement many SWC measures in places where food security is an issue (Tebebu et al. 2010). In the study watershed, the implementation of sustainable land management program has contributed to the efforts towards reducing gully development and expansion (Jahantigh and Pessarakli 2011). In this line, a study by Tarekegn (2012) demonstrated that the rate of gully erosion was reduced from $68.2 \mathrm{t} \mathrm{ha}^{-1}$ year $^{-1}$ in 2010 to $9 \mathrm{t} \mathrm{ha}^{-1}$ year $^{-1}$ in 2016 in our study.

The results of the previous studies are not transferable to our study sites due to differences in biophysical and socioeconomic settings. Therefore, the present study was conducted in Chentale watershed, Blue Nile basin, Ethiopia, to estimate the contribution of gully erosion processes to sediment production at the outlet of the sub-watershed and identify the spatial and temporal variability of soil loss in gully erosion at the outlet of the watershed. We hypothesized that gully erosion will have significant contribution to the production of sediment in the watershed and display both temporal and spatial variability.

\section{Materials and methods}

\section{Description of study area}

Chentale watershed $\left(10^{\circ} 47^{\prime} 51^{\prime \prime}\right.$ and $10^{\circ} 46^{\prime} 58^{\prime \prime}$ North and $37^{\circ} 03^{\prime} 21^{\prime \prime}$ and $37^{\circ} 04^{\prime} 02^{\prime \prime}$ East) is in Ethiopian high lands in the Blue Nile Basin (Fig. 1). It is about $140 \mathrm{~km}$ from Bahir Dar to the south, and $10 \mathrm{~km}$ from the Woreda town, Tillile. It covers an area of $483.6 \mathrm{ha}$, and we selected a sub-section covering an area of 104.6 ha and nested gully catchment area of 13.5 ha was gauged at the upper part of sub-watershed. The Chentale watershed has a sub-humid climate, and the elevation ranges from 2200 to $2700 \mathrm{~m}$ above sea level (masl) as well as the slope of the watershed varies between 3 and 57\%. It receives an annual rainfall between 1400 and $1700 \mathrm{~mm}$. The average minimum and maximum annual temperature is $18{ }^{\circ} \mathrm{C}$ and $25^{\circ} \mathrm{C}$, respectively.

The watershed is dominated by cultivated land covering $91 \%$ of the watershed, whereas forest and grazing land covers about 8 and 1\%, respectively (Fig. 1). Wheat, pea, bean, barley and teff are primary crops grown in the watershed. The soils in the watershed are classified as Nitosols and Vertic-Nitosols. Nitosols which are found in the upper part of the watershed are rich in deep red clay soil. The Vertic-Nitosols are also located in the foot slope part of the

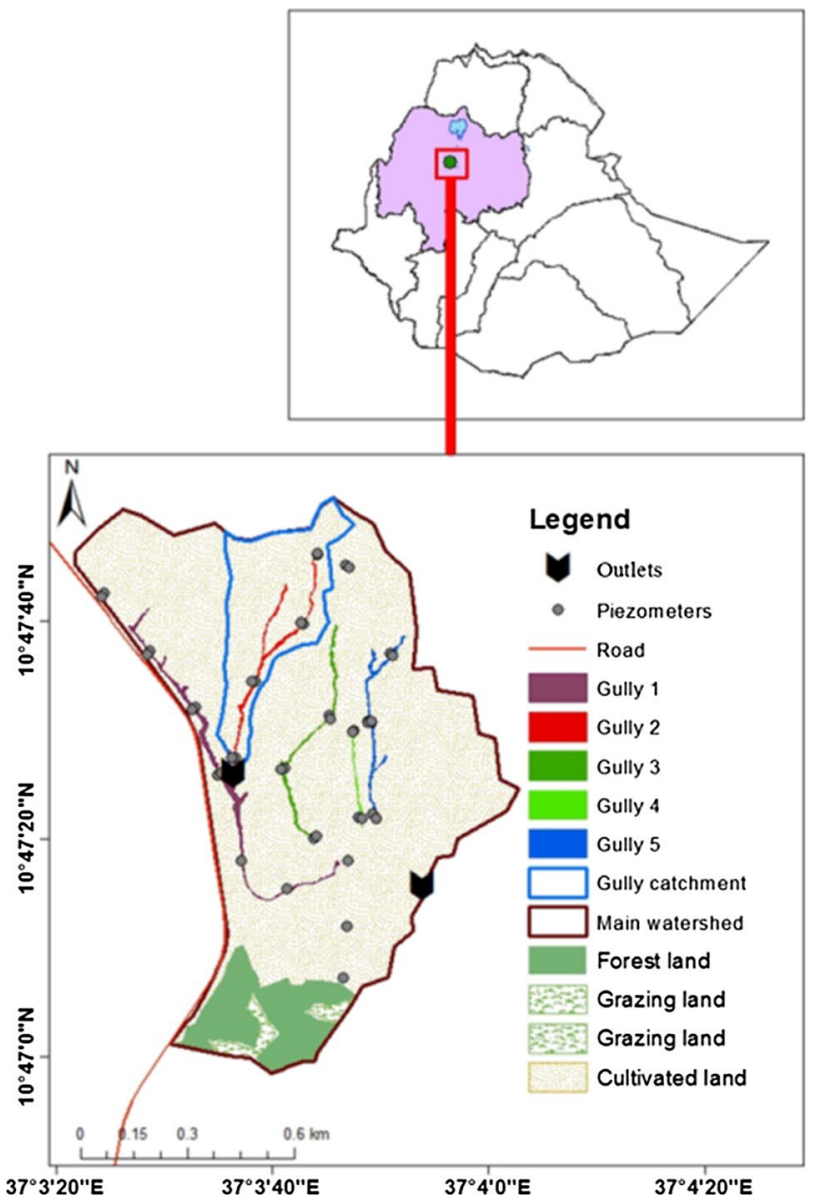

Fig. 1 Map of Ethiopia, Blue Nile Basin, Lake Tana, Chentale watershed and gullies in the watershed

watershed near to the outlet. It is reddish-brown which has a capability to drain and hold water when it gets wet and dry, respectively. It is mostly suitable for teff production.

\section{Data collection and analysis}

\section{Temporal changes in gully dimension}

To determine the temporal changes in gully erosion, historical gully assessment (HGA) method that involved interviews of farmers with different age was used (Radtke et al. 1996). In this line, we selected 4, 3 and 3 farmers with age of 30 , 50 and 70 , respectively, to conduct participatory field observation. During the field observation, issues such as occurrence and expansion rate of gullies were discussed, and an event calendar was developed. Also, we interviewed natural resource and agricultural experts employed by government, to triangulate the information generated through field observation and discussion with participated farmers. Further, we reconstructed sequences of cross sections and longitudinal profiles of the gully, and used Google earth images of 2005 
and 2013 in order to determine the temporal changes of gully networks and dimensions (Martínez-Casasnovas 1998). This activity also supported to estimate the area of the eroded materials during the two periods (i.e., between 2005 and 2013).

Our approach, (the assessment of gully erosion rates through interviews and measurements), allows the assessment of the temporal change of gully dimensions. In combination with precise measurements of short-term changes, the evolution of approximate gully dimensions since incision can be reconstructed and gully erosion rates calculated (Nyssen et al. 2006).

$\mathrm{RL}=\frac{V B_{\mathrm{d}}}{T C}$

$\mathrm{RS}=\frac{\left(V-V_{\mathrm{o}}\right) B_{\mathrm{d}}}{T C}$

where RL is area-specific long-term gully erosion rate in $\mathrm{t} \mathrm{ha}^{-1}$ year $^{-1}$, RS is area-specific short-term gully erosion rate in $\mathrm{t} \mathrm{ha}^{-1}$ year $^{-1}, V$ is total gully volume in $\mathrm{m}^{3}, V_{\mathrm{o}}$ is initial gully volume at the beginning of considered time span (before rainy season) in $\mathrm{m}^{3}, T$ is time span considered in years, $B_{\mathrm{d}}$ is soil bulk density $1.24 \mathrm{~g} \mathrm{~cm}^{-3}$, and $C$ is catchment area in ha.

\section{Changes in gully volume and soil loss}

To estimate soil loss due to gully erosion, we selected 5 gullies (G1, G2, G3, G4 and G5; Fig. 1) within the Chentale watershed. Before measuring the dimensions of selected gullies, we subdivided the cross sections of them in 15 and $25 \mathrm{~m}$ interval, depending on their morphology. Then, the width and depth of each point cross section of a gully were measured at three points (i.e., top, middle and bottom) in 2016 using a measuring tape. Each measurement was taken before and after the rainy season when the groundwater table was below the gullies bottom. We estimated the volume of a cross section of a gully by multiplying cross-sectional area by length of the cross section. The changes in gully volume (or the volume of eroded material) were calculated by subtracting the gully volume before the rainy season from the gully volume after the rainy season. The soil loss due to gully erosion $\left(\mathrm{t} \mathrm{ha}^{-1} \mathrm{year}^{-1}\right)$ was estimated by multiplying the change in gully volume $\left(\mathrm{m}^{3}\right)$ by bulk density (considered as $1.24 \mathrm{~g} \mathrm{~cm}^{-1}$ ) (Tarekegn 2012) and dividing it by the area of the watershed.

\section{Stream flow and sediment concentration}

To measure stream and base flows, two stone masonry weirs: weir-1 (W-1) and weir-2 (W-2) were established at the outlet of the sub-watershed and gully-2 catchment, respectively
(Fig. 1). Storm runoff depth and surface velocity were measured at the two weirs in 2015 and 2016 rainy seasons in every 15-20 min intervals. The measurement was conducted every 20 and 15 min interval for $\mathrm{W}-1$ and $\mathrm{W}-2$, respectively. The change in W-2 was due to the small size of the catchment and to capture all peaks. To calculate surface velocity, we dropped the floater at $15 \mathrm{~m}$ to the upstream of the weir and recorded the travel time to reach the weir. The calculated flow velocity at the surface was multiplied by two-thirds to get actual velocity (Tilahun et al. 2015). The instant discharge was also calculated by multiplying the actual velocity with cross-sectional area of the weir at measured depth. Rating curve was developed for each weir plotting the depth versus discharge to estimate the discharge during nighttime. A power function was fitted to develop the relationship between depth and discharge to weir-1 (Fig. 2), whereas power function for the depth of below $25 \mathrm{~cm}$ (Fig. 3a) and second-degree polynomial for depth of greater than $25 \mathrm{~cm}$ (Fig. 3b) were best fit to weir-2. The calculated discharge was divided by contributing area of the watershed to get runoff in depth units.

One litter water sample collected in every 15-20 min intervals was used to compute sediment concentration. In 2015, the sampling periods were extended from 27 June to 21 November, whereas it extended from 21 May to 14 October, 2016. Then, we filtered the water samples using standard filter paper, oven-dried the sediment in $104{ }^{\circ} \mathrm{C}$ for $24 \mathrm{~h}$ and weighed. From the collected runoff water samples, the sediment concentration of the single sample was estimated by using gravimetric method. We calculated the sediment yield by multiplying sediment concentration with calibrated discharge and summed up over the season to estimate the total soil loss from the watershed.

\section{Shallow groundwater assessment}

To determine the perched groundwater table and assess the effects of groundwater levels on gully expansion, 36 piezometers were installed along the gully on both sides in 2015 and 2016. Piezometer was constructed from 50-mm-diameter

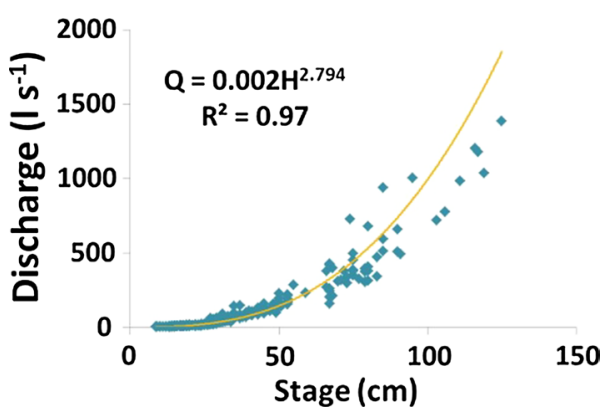

Fig. 2 Stage-discharge relationship at weir-1 
Fig. 3 Stage-Discharge relationship at weir-2 (a $H \leq 25 \mathrm{~cm}$ and $\mathbf{b} H>25 \mathrm{~cm}$ )
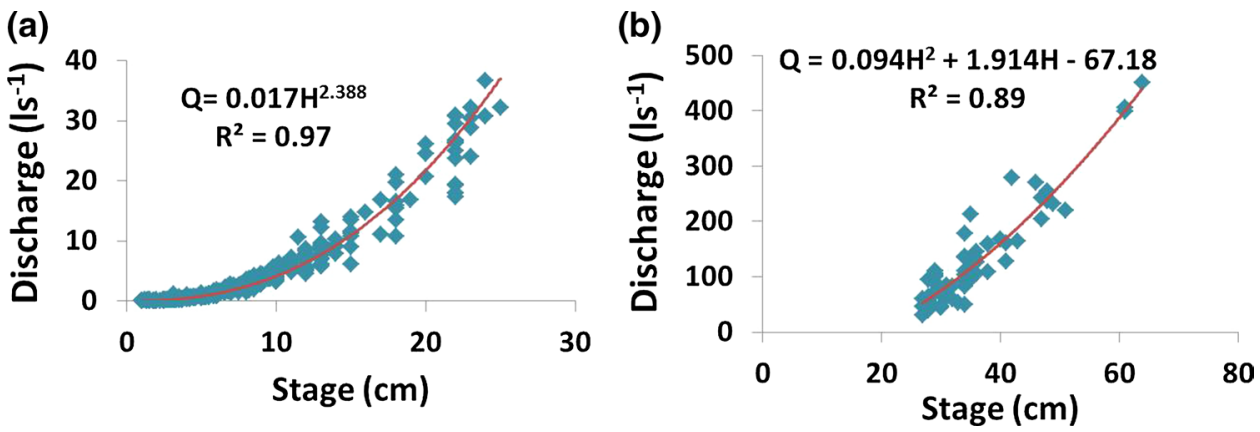

Table 1 Gully plain area and its change between 2005 and 2013

\begin{tabular}{llll}
\hline Variables & \multicolumn{2}{l}{ Area (ha) } & Change \\
\cline { 2 - 3 } & 2005 & 2013 & \\
\hline Gully-1 & 0.76 & 1.20 & 0.44 \\
Gully-2 & 0.30 & 0.66 & 0.36 \\
Gully-3 & 0.30 & 0.73 & 0.43 \\
Gully-4 & 0.07 & 0.08 & 0.01 \\
Gully-5 & 0.41 & 0.81 & 0.40 \\
Total & 1.84 & 3.48 & 1.64 \\
\% coverage & 1.76 & 3.28 & 1.52 \\
\hline
\end{tabular}

PVC pipe perforated with 6-mm-diameter pores at one end which was $30 \mathrm{~cm}$ long and covered with a porous cloth ("Abujedi") to control the entrance of silt in to the PVC pipe. Fifteen to twenty centimeters of the PVC was left above the surface of the ground and covered with a removable plastic cap to protect the entrance of rainfall and surface runoff in to the pipe. The perched groundwater level below the surface was estimated by subtracting the water level in the piezometer from the total depth of the piezometer.

\section{Results and discussion}

\section{Temporal changes in gully expansion}

The results indicated that the area affected by gully erosion in the Chentale watershed increased from 1.84 to 3.48 ha in 8 years (i.e., from 2005 to 2013, Table 1). This is translated to $89 \%$ increase during the study period and also indicates that an area of about 0.2 ha year $^{-1}$ or $0.19 \%$ of the watershed was affected by gully erosion annually. In the same watershed, study by Tarekegn (2012) revealed that the gullies expansion rate was 0.052 ha year $^{-1}$ in 2010 , which is $0.12 \%$ of the watershed, was changed to the gully, whereas in Debre-Mewi watershed, the plain area covered by the gully in the watershed in 2007 and 2008 was 1 and 1.43 ha, respectively. It is increased by 0.43 ha year $^{-1}$ (i.e., surface area covered by the gullies was $0.45 \%$ ) (Tebebu 2009).
Table 2 Gully incision time in Chentale watershed according to information from the respondents

\begin{tabular}{|c|c|c|c|c|}
\hline Variables & Incision time & Age & $\begin{array}{l}\text { Long-term gully } \\
\text { erosion rate } \\
\left(\mathrm{t} \text { year }{ }^{-1}\right)\end{array}$ & $\begin{array}{l}\text { Long-term gully } \\
\text { erosion rate } \\
\left(\mathrm{t} \mathrm{ha}^{-1} \text { year }^{-1}\right)\end{array}$ \\
\hline Gully-1 & 1980 & 36 & 474 & \\
\hline Gully-2 & 1987 & 29 & 478 & 35.4 \\
\hline Gully-3 & 1987 & 29 & 523 & \\
\hline Gully-4 & 1984 & 32 & 90 & \\
\hline Gully-5 & 1980 & 36 & 324 & \\
\hline Total & & 30 & 1889 & 18 \\
\hline
\end{tabular}

When we compared the gully erosion rate of the Chentale watershed with others such as Debre-Mewi, the gully erosion rate of Chentale watershed was lower especially after soil and water conservation work is implemented.

The discussion with farmers during the participatory field observation supports that gullies formation in the watershed started recently and they mentioned that gullies did not exist 3-4 decades ago. The key informants participated in the field observation mentioned that gully formation started in the 1980s following the construction of small drainage ditches used to divert water from agricultural lands. The key informants further elaborated that the small drainage ditches keep eroding with time and start forming shallow gullies (Table 2). According to the respondents, gully-1 (G-1) formation was started in 1980 due to the watershed flow direction change (Fig. 1) for asphalt road construction, and this gully was highly enlarged until 2010 . According to the farmers, gully rehabilitation in the watershed implemented in 2010 and 2011, and further expansion of gullies have been controlled. Before the implementation of the rehabilitation work, it was difficult to cross gully-1, but now it is filled up with sediment and used as a footpath (Fig. 4).

\section{Gully erosion and soil loss in the watershed}

The gully expansion rate monitored from the sidewall, bottom and length indicated that all gullies were not active from the head. All gullies except gully-4 reached at the top of the 
Fig. 4 Bottom part of gully- 1 a picture indicating the gully after rehabilitation, red lines indicate the extent of gully before it rehabilitated and $\mathbf{b}$ picture showing sediment deposition in 2016 rainy season
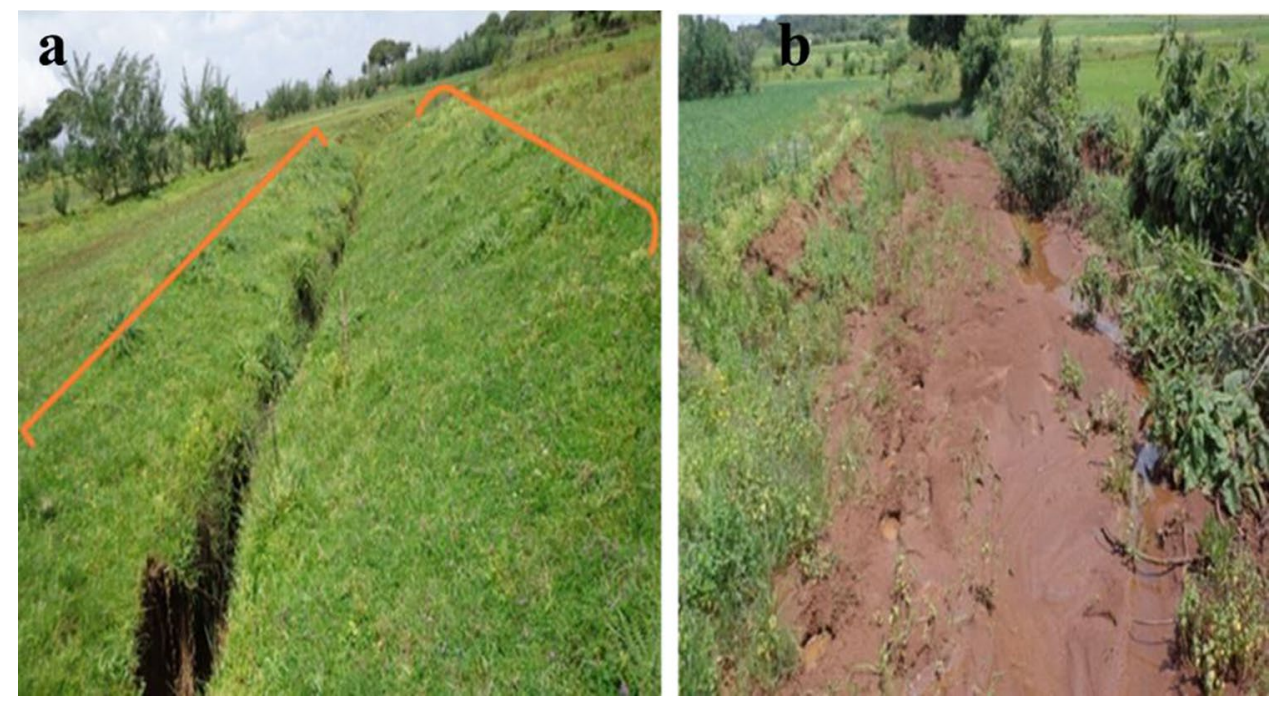

Table 3 Short-term gully erosion rate measured in 2016

\begin{tabular}{lrll}
\hline Variables & Length $(\mathrm{m})$ & Soil loss (ton year & \\
& & & $\begin{array}{l}\text { Soil loss } \\
\left.\text { ton ha }^{-1} \text { year }^{-1}\right)\end{array}$ \\
\hline Gully-1 & 1140 & -108 (deposition) & \\
Gully-2 & 736 & 360 & 26.67 \\
Gully-3 & 927 & 291 & \\
Gully-4 & 270 & 45 & \\
Gully-5 & 568 & 331 & 9 \\
Total & 3641 & 919 & \\
\hline
\end{tabular}

watershed. The main sediment source of gullies in study area was from the sidewall and bottom parts. Small drainage ditches installed in the farm area were connected to the gullies. Gullies expanded highly from the side-wall at the point where the farm drainage ditches connected with the gullies and it created another gully branch, but now concentration of farm drainage ditches were reduced. According to the assessment conducted in 2016 (Table 3), the gully plain area covered a total area of 2.34 ha or $2.23 \%$ of the total watershed area (104.65 ha). This indicates that gullies have been expanding by 0.02 ha year $^{-1}$ and resulted in a soil loss of $9 \mathrm{t} \mathrm{ha}^{-1}$ year $^{-1}$. However, the long-term erosion rate from the outlet of the main watershed and gullies catchment areas was estimated at 18 and $35.33 \mathrm{t} \mathrm{ha}^{-1}$ year $^{-1}$, respectively, indicating that the recent implementation of soil and water conservation practices in the watershed contributed to the reduction in soil loss due to gullies.

Many researchers reported that erosion rates vary greatly across different agro-ecologies (Bayabil et al. 2015; Tebebu et al. 2015). Soil loss rates are greater from areas with rainfall over $1000 \mathrm{~mm}_{\text {year }}{ }^{-1}$ and with a sub-humid or humid climate than in the arid and semi-arid areas (Bayabil 2015). Sediment yield from Anjeni watershed was ranged between 1 and $161 \mathrm{t} \mathrm{ha}^{-1}$ year $^{-1}$ at different experimental plots (Bayabil 2015). In Debre-Mewi watershed, where active gulling is taking place, erosion rates ranged from 31 to $530 \mathrm{t} \mathrm{ha}^{-1}$ year $^{-1}$ at sub-watershed level depending on the severity of the gulling (Tebebu et al. 2010). The cumulative soil loss rate from rills was also approximately $60 \mathrm{t} \mathrm{ha}^{-1}$ year $^{-1}$ (Tilahun et al. 2014), whereas in Chentale watershed the rills were not observed. Compared to other watersheds, the sediment yield of Chentale watershed was low (2-9 $\mathrm{t} \mathrm{ha}^{-1}$ year $\left.^{-1}\right)$ in 2015 and 2016. It is due to soil and water conservation work and gullies have been rehabilitated.

Researches revealed that initially, gully erosion rate is slow then highly expand and the rate decreases at the end (Nyssen et al. 2006; Tarekegn 2012). Chentale watershed gully expansion rate become stable, and it is at the end stage. Tarekegn (2012) reported that the erosion rate of gully- 2 was $292 \mathrm{t} \mathrm{ha}^{-1}$ year $^{-1}$, and for gully-1, it was $83 \mathrm{t} \mathrm{ha}^{-1}$ year $^{-1}$, and the area-weighted average of all three gullies (gully-1, gully-2 and gully-3) was $68.2 \mathrm{tha}^{-1}$ year $^{-1}$. But in 2016, the gully erosion rate of gully-2 was $26.6 \mathrm{t} \mathrm{ha}^{-1}$ year $^{-1}$ and the weighted average of all 5 gullies was $9 \mathrm{t} \mathrm{ha}^{-1}$ year $^{-1}$.

\section{Gully development process and shallow groundwater table}

The distributions of perched groundwater level in the watershed were analyzed by interpolation using GIS technique. The data from piezometers indicated that groundwater table was high at the bottom part of the watershed where it was saturated. The groundwater level near to the asphalt road is high (Fig. 5). This is because the road is perpendicular to the flow direction within the landscape. The infiltrated water and overland flow from the hill made the perched groundwater table shallow at the bottom near to the road. The water table started rising between

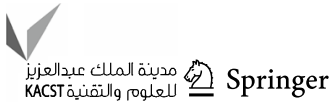




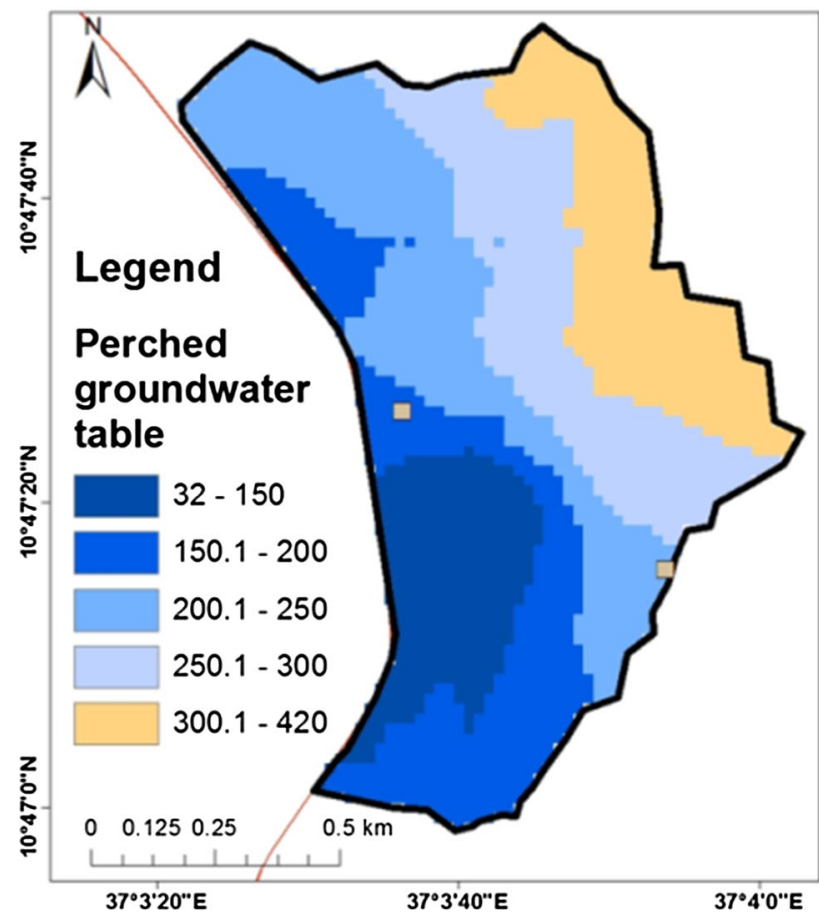

Fig. 5 Spatial distribution of perched groundwater level in 2016; the number in the legend indicates the perched groundwater level below the surface in $\mathrm{cm}$

mid-July and the beginning of August. When the rainy period is ending, the water table in the upper and middle parts of the sub-watershed declines rapidly than the bottom part. The groundwater table at the upper and middle parts of the watershed was below the gully bottom, but at the lower part of the watershed, it was above the gully bottom. The groundwater table at the top part of the gully did not affect gully expansion.

Based on data collected in 2015 and 2016, the monthly rainfall varied between 0 and $395 \mathrm{~mm}$ with a mean monthly rainfall of $140 \mathrm{~mm}$. The groundwater level of 2015 and 2016, the perched groundwater level was lower in 2015 in all monitoring points. This could be due to the difference in rainfall amount and distribution between the 2 years (Fig. 6).

The water table at top part of the watershed was deeper than the gully bottom as shown in Fig. 7 .

In our study of gully formation and expansion process, the gullies are rapidly expanded at the uphill side (Fig. 8). But still there is some erosion from the valley bottom part of the gullies, mostly where the groundwater table is higher than the gully bottom. It is due to static condition of the pore water pressure near the gully walls, which might be sufficient to cause slumping of the gully walls (Fig. 8). Gullies where the groundwater level is above the gully bottom are rapidly expanded and deepen by sliding and scoring from the gully profile, and washed-out the soil from the bottom even in small water pressure during storm runoff is occurred. It is

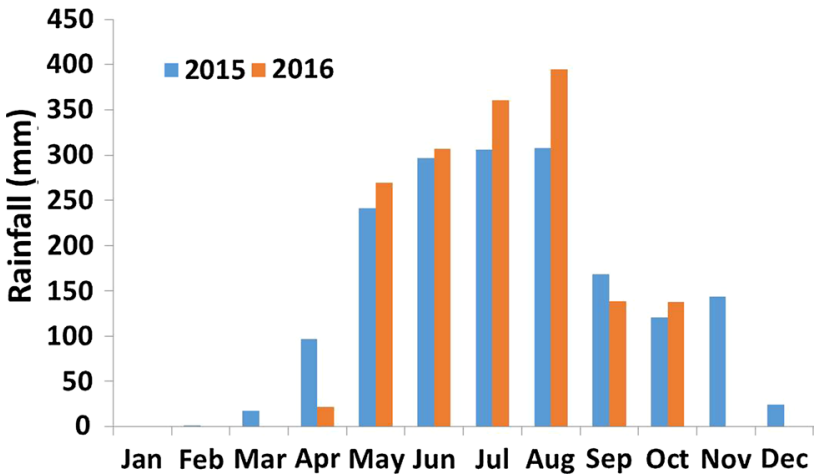

Fig. 6 Monthly rainfall distribution

likely due to less soil resistance force due to pore water pressure (Tebebu et al. 2010).

\section{Sediment concentration and yield from the entire watershed and gullies catchment}

According to the respondents, the runoff, sediment load and the numbers of drainage furrows were reduced following the implementation of soil and water conservation measures. Farmers witnessed that before the last 2 decades, there are no perennial springs in the watershed, but after soil and water conservation implementation 3 springs flowing throughout the year were observed at the bottom part of the watershed. And the amount of flow is increasing over time compared to the last 2 decades. This has led to improved dry season flow and expansion of small-scale irrigation use for vegetables production.

In 2015, sediment concentration was higher in July and August at the gully catchment and main watershed, respectively, whereas it was higher in June and July in 2016 (Fig. 9). This could be attributed to the difference in amount and distribution of rainfall between the 2 years.

The sediment yield in 2015 from the main watershed and gullies catchment was 6.43 and $2 \mathrm{tha}^{-1}$ year $^{-1}$, respectively. In 2016, it was 7 and $9 \mathrm{t} \mathrm{ha}^{-1}$ year $^{-1}$, respectively. In 2016, less sediment concentration and yield at the outlet of main watershed when compared to the results from gullies catchment indicated that gullies were the main source of soil erosion when concentrated rainfall and high surface runoff were observed and vice versa.

\section{Conclusion}

Access to reliable and relatively simple methods is required to assess the temporal and spatial variability of sediment derived from gully erosion. The method 
Fig. 7 The gully and perched groundwater table

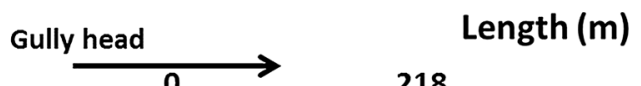

218

424

651

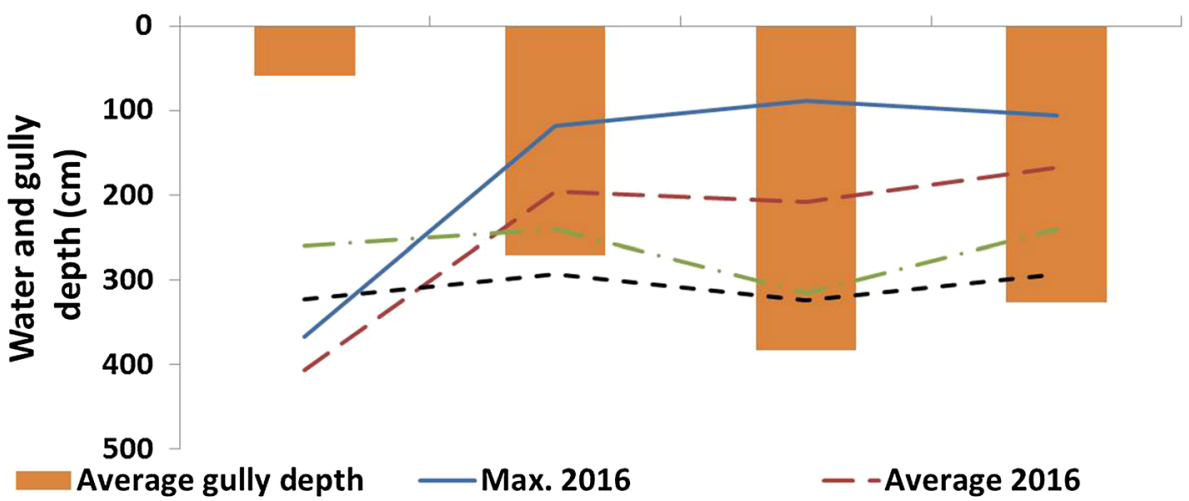

- Max 2015

- - Average 2015

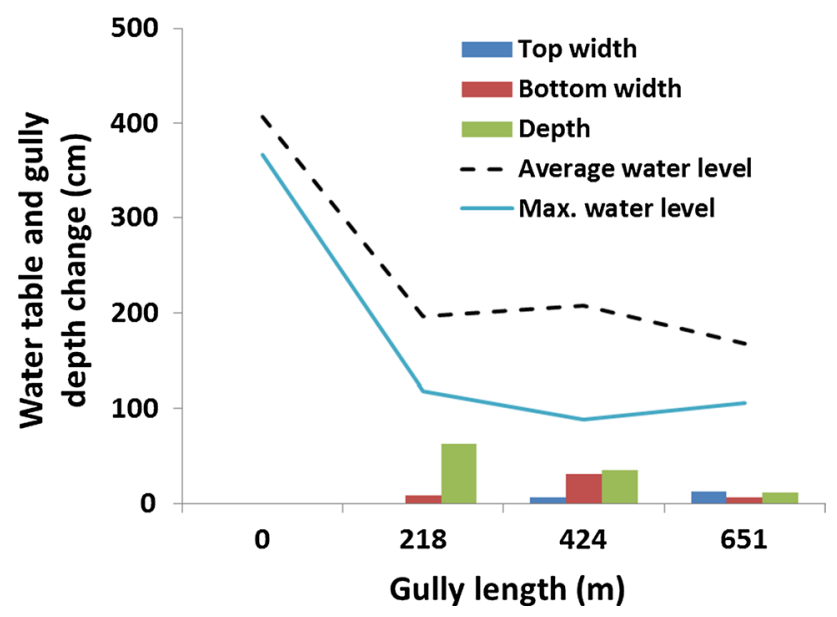

Fig. 8 Gully profile change due to perched groundwater table

described here used to assess this variability is built on both historical and current understanding of gully behaviour. It allows estimating historic and contemporary gully erosion rates. The result from the assessment indicates that a decrease of gully development was observed after 2013, and especially in the most recent years. The short-term gully erosion rate is two times lower than the long-term gully erosion rate, indicating that gullies are in the stabilizing phase. This is due to soil and water conservation practice implementation including the rehabilitation of gullies using biophysical measures since 1995 . The landscape of the watershed plays an important role to confine the gully erosion rate. The steep part of the watershed was most vulnerable to gully expansion than gentle area. The results support that integrated soil and water conservation measures are required to reduce soil erosion due to gullies.

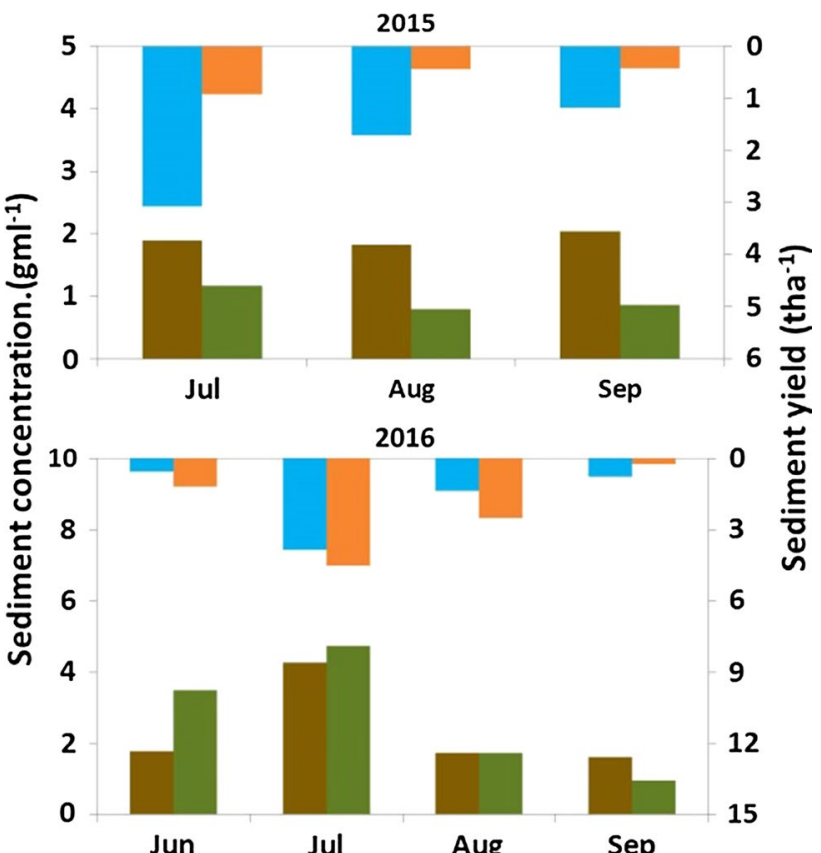

weir-1 sediment concentration $\quad$ Weir-2 sediment concentration

Weir-1 sediment yield

Weir-2 sediment yield

Fig. 9 Monthly sediment yield and average sediment concentration at the gauging outlets

Acknowledgements This research was made possible through support provided by CGIAR Research Program on Water, Land and Ecosystem's East Africa focal regional program.

\section{Compliance with ethical standards}

Conflict of interest The authors declare that they have no conflict of interest.

Open Access This article is licensed under a Creative Commons Attribution 4.0 International License, which permits use, sharing, 
adaptation, distribution and reproduction in any medium or format, as long as you give appropriate credit to the original author(s) and the source, provide a link to the Creative Commons licence, and indicate if changes were made. The images or other third party material in this article are included in the article's Creative Commons licence, unless indicated otherwise in a credit line to the material. If material is not included in the article's Creative Commons licence and your intended use is not permitted by statutory regulation or exceeds the permitted use, you will need to obtain permission directly from the copyright holder. To view a copy of this licence, visit http://creativecommons .org/licenses/by/4.0/.

\section{References}

Bayabil HK (2015) Hydrological and erosion processes in the Ethiopian Highlands. Cornell University, Ithaca

Bayabil H, Tebebu TY, Stoof C, Steenhuis T (2015) Spatial and temporal runoff processes in the degraded Ethiopian Highlands: the Anjeni Watershed. Hydrol Earth Syst Sci Discuss 12(4):4387-4411

Carey B (2006) Gully erosion. In: Fact sheets: land series, Rep L81

Descheemaeker K, Nyssen J, Poesen J, Raes D, Haile M, Muys B, Deckers S (2006a) Runoff on slopes with restoring vegetation: a case study from the Tigray highlands. Ethiop J Hydrol 331(1-2):219-241

Descheemaeker K, Nyssen J, Rossi J, Poesen J, Haile M, Raes D, Muys B, Moeyersons J, Deckers S (2006b) Sediment deposition and pedogenesis in exclosures in the Tigray Highlands. Ethiopia Geoderma 132(3-4):291-314

Desta L, Adugna B (2012) A field guide on gully prevention and control. Nile Basin Initiative Eastern Nile Subsidiary Action Program (ENSAP), Addis Ababa, Ethiopia 67

Desta G, Hurni H (2011) Farmers' participatory soil erosion assessment and soil conservation improvement: application of local erosion indicators. Eastern and Southern Africa Partnership Programme-Centre for Development and Environment (ESAPPCDE), Bern

Hurni H (1988) Degradation and conservation of the resources in the Ethiopian highlands. Mt Res Dev 8:123-130

Jahantigh M, Pessarakli M (2011) Causes and effects of gully erosion on agricultural lands and the environment. Commun Soil Sci Plant Anal 42(18):2250-2255

Lakew BA, Nile Basin (2012) Gully prevention and control

Martínez-Casasnovas JA (1998) A methodology to compute the rate of gully erosion from multitemporal analysis of aerial photographs and digital elevation models

Moges A, Holden N (2008) Estimating the rate and consequences of gully development, a case study of Umbulo catchment in southern Ethiopia. Land Degrad Dev 19(5):574-586
Moges MA, Schmitter P, Tilahun SA, Langan S, Dagnew DC, Akale AT, Steenhuis TS (2016) Suitability of watershed models to predict distributed hydrologic response in the awramba watershed in lake Tana basin. Land Degrad Dev 28:1386-1397

Nyssen J, Poesen J, Moeyersons J, Luyten E, Veyret-Picot M, Deckers J, Haile M, Govers G (2002) Impact of road building on gully erosion risk: a case study from the northern Ethiopian highlands. Earth Surf Process Landf J Br Geomorphol Res Group 27(12):1267-1283

Nyssen J, Veyret-Picot M, Poesen J, Moeyersons J, Haile M, Deckers J, Govers G (2004) The effectiveness of loose rock check dams for gully control in Tigray, northern Ethiopia. Soil Use Manag 20(1):55-64

Nyssen J, Poesen J, Veyret-Picot M, Moeyersons J, Haile M, Deckers J, Dewit J, Naudts J, Teka K, Govers G (2006) Assessment of gully erosion rates through interviews and measurements: a case study from Northern Ethiopia. Earth Surf Proc Land 31(2):167-185

Radtke R, Lenz P, Showers W, Moksness E (1996) Environmental information stored in otoliths: insights from stable isotopes. Mar Biol 127(1):161-170

Tarekegn BC (2012) A case study of gully erosion in the Ethiopian highlands: the Warke Watershed. Citeseer

Tebebu TY (2009) Assessment of hydrological controls on gully formation near Lake Tana, northern highlands of Ethiopia. Citeseer

Tebebu T, Abiy A, Zegeye A, Dahlke H, Easton Z, Tilahun S, Collick A, Kidnau S, Moges S, Dadgari F (2010) Surface and subsurface flow effect on permanent gully formation and upland erosion near Lake Tana in the northern highlands of Ethiopia. Hydrol Earth Syst Sci 14(11):2207-2217

Tebebu TY, Steenhuis TS, Dagnew DC, Guzman CD, Bayabil HK, Zegeye AD, Collick AS, Langan S, MacAlister C, Langendoen EJ (2015) Improving efficacy of landscape interventions in the (sub) humid Ethiopian highlands by improved understanding of runoff processes. Front Earth Sci 3:49

Tilahun SA, Guzman CD, Zegeye AD, Ayana EK, Collick AS, Yitaferu B, Steenhuis TS (2014) Spatial and temporal patterns of soil erosion in the semi-humid Ethiopian highlands: a case study of Debre Mawi watershed Nile River Basin. Springer, Berlin, pp 149-163

Tilahun SA, Guzman CD, Zegeye AD, Dagnew DC, Collick AS, Yitaferu B, Steenhuis TS (2015) Distributed discharge and sediment concentration predictions in the sub-humid Ethiopian highlands: the Debre Mawi watershed. Hydrol Process 29(7):1817-1828

Publisher's Note Springer Nature remains neutral with regard to jurisdictional claims in published maps and institutional affiliations. 